VITALII SHCHERBAK,

Borys Grinchenko Kyiv University (Kyiv, Ukraine)

e-mail:shcherbak.vitalii@gmail.com,ORCID0000-0001-8025-5684

\title{
ORTHODOXY AS A FIGHT FLAG FOR COSSACK AUTONOMY WITHIN THE POLISH-LITHUANIAN COMMONWEALTH
}

\begin{abstract}
The relevance of the article is conditioned by the need to uncover the genesis of state-developing processes in Ukraine as part of the European socio-cultural space of New time. The purpose of the study is to find out the basic principles and ways of forming the idea of Cossack autonomy in the Polish-Lithuanian Commonwealth at the end of XVI - the first half of XVII c. The methodology is based on the application of general scientific (analysis, synthesis, retrospection) and specifically historical (problem-chronological, historical-comparative and critical-analytical) methods of scientific research. It clarifies the genesis of the self-government of the Zaporozhye community and the extension of its principles to the Dnieper region. Key focus is dedicated to the role of Orthodoxy in this process via the leaders of Zaporozhian Army and Ukrainian high clergy. The author proves that the principles of self-government as an important factor of autonomy were formulated in Zaporozhian Sich. This led to the appearance of various political projects, where the leading role was assigned to the Zaporozhian Army. The union of the Cossack elite with the Orthodox hierarchs promoted an awareness of the positions of both parties in the conditions of Polish expansion. It was fully manifested during the Cossack rebellions in Ukraine in the 20-30s of the XVII c., which led to the formation of the idea of Cossack autonomy within the Polish-Lithuanian Commonwealth. The results of the research will contribute to the study of the evolution of the state idea in early modern Ukraine.
\end{abstract}

Keywords: Ukrainian Cossacks; Cossack autonomy; Orthodoxy; Zaporozhian Army; clergy.

Introduction

It is difficult to overestimate the value of the confessional factor in the life of early modern society. It dominated the moral values, really influenced the social behavior of the individual and the whole stratas of the population. The religious issue became of extreme urgency in Ukraine after the Brest Union in 1596, which was manifested in the speeches of the Orthodox nobility at the gatherings and meetings, in the works of polemic writers, and in the activities of fraternities. However, the most effective power in upholding of Orthodoxy was the Cossacks. The key to success was the close alliance of Zaporozhian Army leaders with senior clergy of the Ukrainian Orthodox Church. Each side set its own goal, but their tasks were often consensual. Cossacks' fight for strata rights went alongside with the upholding of the Orthodox faith and the growth of power that the Orthodox clergy could rely on in the conditions of Catholic expansion in Ukraine. This topic was partially covered in national historiography. For example, Mikhailo Hrushevsky provided a wide picture of the Cossacks' fight for class rights and privileges (Hrushevsky, 1995). Volodymyr Holobutsky (Holobutsky, 1994) emphasized the social factor of the Cossack movement's deployment. The author of this work has analyzed the importance of the confessional factor in the formation of the Cossack strata (Shcherbak, 2006). However, the role of Orthodoxy in shaping the idea of Cossack autonomy remained unaddressed. The purpose of this article is to find out the grounds of Cossacks' autonomy in the PolishLithuanian Commonwealth and the role of the confessional factor in it.

Methods

The methodological basis of the article is the principles of historicism, systematicity and objectivity in the approach to clarify events in the past. General scientific (analysis, synthesis, retrospection) and specific historical (problemchronological, historical-comparative, critical-analytical) methods are used while solving stated tasks.

\section{Results}

The modern concept of autonomy - the special status of entities that exist within a state on the basis of broad self-government, is incorrectly applied unconditionally to the early modern era. At the same time, self-government is a fundamental principle of legalized independace. The fact of recognition was, as a rule, based on the formed phenomenon, the duration of which was different. This thesis is quite adequate to the genesis of the idea of Cossack autonomy within the Polish-Lithuanian Commonwealth.

It is quite obvious that Zaporozhian Sich did not have a separate legal status, but the absence of legal grounds does not deny the fact of its existence with specific selfgovernment in the second half of the XVI c. It initiated the idea of the Zaporozhye community as a self-sufficient military and political union in relations not only with the government of the Polish-Lithuanian Commonwealth, but also with the outside world. The Cossack system envisaged the functioning of the Cossack Council, which addressed the most important issues of community life through a narrow circle of senior leaders, which is led by the otaman. So there was actual autonomy in Zaporozhye, which is designated in the national historiography as "the Cossack Christian Republic" (Nalyvaiko, 1992). Its priority values were knightly dignity and fight against enemies of Orthodoxy.

Separate elements of the autonomy of Zaporozhian 
Sich at the end of the XVI c. spread to the populated areas during the Cossack rebellions. In the territories controlled by the rebels, local authorities were liquidated and selfgovernment was established similar to the Zaporozhye one. Feeling the real threat to its existence, local officials repeatedly appealed to the higher state authorities in order to suppress the "Cossack outrage". Cherkasy and Kaniv head Oleksandr Vyshnevetsky wrote to the royal chancellor Jan Zamoysky that the chief of the Zaporozhian army registry, Christopher Kosinsky, having collected two thousand Cossacks, "spilled the blood of innocent (nobility. - V.Shch.) in royal lands, castles, cities, and other possessions of nobles were burned, devastated ..., wanted to turn upside down all the royal border lands and cut us all out" (Listy, 1886: 27). O. Vyshnevetsky also noted the intention of the Cossack leader to submit to the rule of the Moscow tsar. The Polish chronicler Martin Bielski even wrote that Christoph Kosinsky sought to do more than "harm" towards Prince Konstantin Ostrozky (Kronika, 1856. 1689). The nobility also stressed anxiety in an appeal from January 11,1593 to the Lutsk city court. According to its statement, the Cossacks in Volhyn "force to swear allegiance" (Archive, 1863: 39).

The result of noble reports was the appearance of the constitution of the general seim as of June 15,1593, which in particular stated: "people, who arbitrarily gather in groups without permission, committing assaults and violence or intending to cross illegally the border of our country, should be considered enemies of their homeland and traitors, and therefore hired (kwartz) detachments can be sent against them in case of necessity without any litigation; each of them should defend himself against them in their houses and estates" (Peasant Movement, 1993: 346).

Numerous complaints of the nobility were observed in the next three years. From Bratslavshchina it was reported that the Cossacks abolished the local administration, taxed noble property with indemnity and set their own court. Mikhailo Hrushevsky suggested the possibility of threatening by Cossack leaders against the Polish-noble regime (Hrushevsky, 1995, 7: 306). Without denying this thesis, it should be noted that the lack of documentary evidence directly from the Cossack environment, as well as the thoughtful and corrected actions of the rebels aimed at counteracting foreign domination, cast doubt on it. Another thing is how Cossacks' enemies perceived the situation. Thus, the Crown Hetman Stanislav Zholkiewski wrote in a letter to King Sigismund III from military camp near Supoy river on May 21, 1596: "It is disgusting to recall what they told about you, in which terms they mentioned your royal mercy, which plans they made about Krakiw, the glorious capital of your royal mercy, concerning the demolition and destruction of the noble state" (Pisma, 1861: 151). During a conversation with Papal Cardinal Enrico Gaetano with Chancellor Jan Zamoisky in Warsaw, the latter noted that during negotiations of Semeriy Nalyvaiko with the Ambassador of Austrian archduke Maximilian, "anti-Polish plans" took place. The Polish nobility also regarded the acceptance of korogva (flag) by Zaporozhian Cossaks from the German Emperor Rudolf II as treason of the crown of the Polish-Lithuanian Commonwealth. Even after the Solonitsky massacre, taking into account the growing Cossack power, Stanislav Zholkevsky wrote to the King about the need "for fear to place the army (on the Dnieper. - V.Shch.), and also equally necessary thing is that your royal mercy to give orders to starostas and royal land administrators to prevent the beginnings (separate speeches. - V.Shch.), either alone or through their deputies, and not to allow evil to grow" (Listy, 1886: 80). For a deeper persuasion, the hetman offered to severely punish the rebels.

Obviously, it was the knowledge of Cossack attitude that inspired Kiyv Catholic bishop Joseph Vereshchinsky in 1596 to develop a project of organization of the Dnieper Cossack state which is headed by a prince. The military power, according to this project, should belong to the hetman of the Zaporozhian Army. Each of the 13 regiments was not only a military unit but also an administrativeterritorial unit. The colonel also executed the functions of local military and civilian authority. It is significant that the regiment was given land property, which would have to resolve the issue of material support of the Zaporozhian Army (Sas, 1992: 59-61; Wereszczyński, 1911: 12-15).

Thus, bishop Joseph Vereshchinsky made an important step towards the formation of a program of Cossack autonomy. However, the Polish government rejected the project because its developer had unleashed a stereotypical view of the Cossacks as mercenaries and unauthorized soldiers. According to Vereshchinsky, they are just as knights as the nobility, and can expect to obtain the status of full subjects of the Polish-Lithuanian Commonwealth. Even the defeat of the rebellions of the $90 \mathrm{~s}$ did not stop the Cossacks' appeal to knightly ideals and the efforts to be recognized as "crown sons" with claims to the right for the Dnieper lands as an area of their exclusive interests.

The Cossacks' assertion of rights and privileges coincided chronologically with the policy of the Polish-Lithuanian Commonwealth Government in the confessional realm at the beginning of the XVII c. The support of Catholicism and Uniatism led to the oppression of Orthodoxy in Ukraine. In accordance there is a manifestation of Cossack solidarity with the clergy in the face of a common threat. Thus, in the spring of 1610 , the Uniate Metropolitan Ipatii Poti tried to subordinate Kiyv churches and to incite the local clergy towards the Uniate. That end, he sent the governor Anthony Grekovich to Kiyv, but there Orthodoxy felt the support of the Cossack armed forces. Grekovich's call of Kiyv priests to St. Sophia Cathedral for a joint service was unsuccessful. On the contrary, the clergy campaigned among the parishioners, warning that whoever comes to the church will be baptized into another's faith. A small detachment of Cossacks located in front of Sofia, stopping the arriving citizens.

Grekovich sealed the church not to allow the Orthodox to carry out its service. Cossack representatives led by Gregory Sereda, from its side, filed a protest to the Kyiv City Court on behalf of the Zaporozhians against accusation them by the Uniate metropolitan. "And we, also," the document stated, "being the sons of the cathedral apostolic eastern church, by the name of the whole Cossacks Zaporozhians Army ... to their mercy of the peoples of the Orthodox faith and ancient religion and in the face of spiritual persons not secessionists (Uniates. - V.Shch.) and not .... protest against the invasion into our ancient Orthodox church" (Acts, 1865: 59). The striving to defend the ancient Orthodox faith sounded in the letter of the Cossack Hetman Hryhoriy Tiskinevich to the Kiyv voivoda deputy Mikhail Kholonevsky of May 29, 1610: "For our Eastern church and for the Greek faith we will lay our heads . and give our knighty word to defend" (Acts, 1865: 66). There was also a warning, if the Uniate governor did not renounce his intention, he would be punished.

Joint struggle of the Ukrainian Cossacks and the Orthodox clergy was conditioned by refusal of general seim to consider a question of "Greek faith" and the participation of the Cossacks in the campaigns of the Crown Army to Moscow. The respective complains on "Cossacks outrage" from the nobility appeared again in the resolutions of 
various district seims, as well as the proposals to subordinate Cossacts under starostas (admonistrators) jurisdiction. Despite of threatening governmental resolutions, the Cossacks did not recognize starosta's authority and conducted various forms of their own justice. In 1616, one of the ambassadors drew attention of the seim to the fact that the Cossacks did not recognize "neither the magistrates in the cities, nor the starostas or hetmans; they establish their own right, choose their own officials and leaders, and it seems they create own republic in the Great Polish-Lithuanian Commonwealth (Zherela, 1908: 124). One might consider such evaluation as an exaggeration if it were not repeated from time to time.

The significance of the confessional factor in asserting Cossack rights was clearly manifested during the mission of Jerusalem Patriarch Feofan to Ukraine in 1620. Already at the border with Moscow, he was met by hetman of Zaporozhian Army Peter Sagaydachny and escorted to Kiyv. In the house of the Epiphany fraternity in Podil the patriarch was under the protection of magistrate authorities and special Cossack security. Subsequently, Feofanes visited the Cossack Trakhtemir Monastery, Kaniv and Cherkasy, that caused concern of the Polish authorities. There were grounds for concern, since the Ukrainian clergy had benefited with the visit. In its circles it was stated the intention to restore the Orthodox Church hierarchy without the King's consent. This question became a major issue at the congregation which was convened during the temple feast on August 15, 1620 at the Kiev-Pechersk Monastery. Representatives from Volhyn, Podillya, Pokuttya, Pidlashia, Lithuania, together with Cossacks, citizens and Orthodox nobles, requested the patriarch Feofan to perform an act of consecration. Petro Sahaidachny dispersed hesitation and fears of the latter to have "troubles with the King and the Poles" by guaranteeing the patriarch's security when leaving Ukraine. The decisive role of the Cossacks in the restoration of the Orthodox hierarchy is emphasized in the work of lov Boretsky "Protestation": "knightly people and passionate in his spirit (Feofan. - V.Shch.) said: "You would not be Christ's apostolic governor if you did not consecrate or abandon your greatness to the people of the Rusian metropolitan and bishops, leaving us persecuted here and without shepherds" (Boretsky, 1998: 317 ). As a result of such a statement, in October 1620 , Patriarch Feofan consecrated lov Boretsky as Metropolitan of Kiyv and Halych and five Orthodox hierarchs as bishops (Zhukovich, 1906: 43-44).

The understanding of the political situation by the Ukrainian clergy was also traced during the Cossack Council in the area of Sukha Dibrova in the summer of 1621 , where the question of participation in the war with Turkey was decided. Metropolitan lov Boretsky, Bishop of Vladimir Yezikiil Kurtsevich and 300 priests arrived at the council. The Metropolitan called on the Cossacks to defend the Orthodoxy against the "busmurans" (Vikul, 1894: 48). On behalf of the Zaporozhian Army, an embassy headed by Peter Sahaidachny went to the King.

As reported by one of the Uniate publicists, the content of the petition filed by the Cossack ambassadors was reduced mainly to the administration of religious affairs. First of all, it was about the approval of the royal charters of the newly appointed hierarchs in their lands and the abolition of universals recently issued against the Orthodox. In case of acceptance of these requirements, the Cossacks declared themselves to serve the PolishLithuanian Commonwealth (Hrushevsky, 1995, 7: 465).

After the successful completion of the Khotyn war, the Cossacks, which played crucial role in it, did not back down from their demands, including the denominational ones.
Embassy of Cossacks again went to Warsaw. One of the points in their petition concerned the "reassurance of our ancient Greek faith." Sigismund III's refusal to grant the Cossacks' request led to a further escalation of social tension in Ukraine, and in 1625 a new rebellion broke out in the Dnieper region.

The punishers could not resolve the conflict with the help of weapon, instead they concluded a compromised Kurukivska agreement, where the Cossacks achieved rights to assert rights on a certain territory. One of the clauses of the agreement contained information about formation of six registry regiments upon the territorial principle - Bilotserkivskyi, Pereyaslavskyi, Korsunskyi, Kanivskyi, Chyhyrynskyi and Cherkasy. Obviously, it was on the basis of this document requirenments of rebellions led by Taras Fedorovich were formulated in 1630 about the withdrawal of the Crown troops to the West of the Bila Tserkva. By the way, in the Hetman's universals, alongside the Cossack demands, for the first time it was stated "fight for faith". The Crown Hetman Stanislav Konecpolsky also emphasized the religious aspect of the rebellion led by Fedorovich in his speech at the Seim in 1631: "There were letters from some spiritial and secular persons where they stated that their faith is being ruined, churches being taken and they ask for defence; these rumors annoyed poor people and stirred up the whole Ukraine, so that none of the nobility there was safe in their home" (Peasant Movement, 1993: 239).

A clearer definition of the scope that the Cossacks were prepared to defend is contained in the decision of the Korsunska Council of 1632, which it was declared that "they did not give up the peasant faith; if Poles press further on their faith they will appeal to the Tsar and Grand Duke Mikhail Fedorovich of All Russia, so that the sovereign may have welcomed them, ordered to take under his state hand, and they, Belarusians and Cherkasians, will stand on the Dnieper for their faith." (Reunion, 1954, 1: 129). For the first time the Cossacks came up with the idea of asserting their rights in a certain territory, namely Left Bank Ukraine. In essence, it was about the intentions to form own Cossack republic.

In the same year, during the royal election, the Cossacks made a great deal of effort for the appearance of "The Articles to appease the Rusians people", which legalized the Orthodox Church hierarchy in Ukraine and Belarus. Kyiv was recognized as the center of the metropolis. A special commission which was set up at the Coronation Seim was supposed to deal with the redistribution of church property between the Orthodox and the Uniates. An important factor in the stabilization of Orthodoxy was the approval of Petro Mohyla in the post of Metropolitan of Kyiv and Galicia, which was officially recognized by the government of the Polish-Lithuanian Commonwealth. The legalization of the Orthodox Church in Ukraine had little effect on the practice of local administrators. While pursuing governmental policies, they supported the position of Roman Catholics and Uniates in every possible way, despite the constant protests by the Orthodox. The mood of the latter was clearly manifested during the next large-scale Cossack rebellion of 1637-1638. Thus, in the universal as of November 4, 1637, the Cossack Colonel Karpo Skidan addressed not only to the Cossacks, but also to all the "Commonwealth people", calling himself "the guardian of all Ukraine". The message, in particular, stated: "We announce to you, our comrades, that we have received a message about the decisive intentions of the zhovnirs, who are probably already gathering to Ukraine, in which God does not help them. Therefore, by the power of my authority and by the name of the army, I command 
and confirm that you should not be kept safe but to stock up of horses, bread, and weapons, and be ready to withstand as knights against these oppressors of our Greek faith when necessary." (Dyaryusz, 1858: 26). Therefore, the Cossacks' advocacy of corporate interests was accompanied by a desire to protect Orthodoxy in Ukraine.

Referring to the officers of registry army, the Cossack hetman Pavlo But upbraided them for forgetting the decision of the Kurukivska commission, according to which the Crown troops were not to be stationed on the Left Bank. According to one source, he also stated that he hoped to become the "owner of the land of Rusia". In another case Pavlyuk stated: "when the King and the Polish-Lithuanian Commonwealth need the service of the Zaporozhian Army against some enemy, we will all unanimously depart from our places at the call of the King and his ambassadors; and when there is no need in the Zaporozhian Army, whoever wants to live under military kleynodes in Zaporozhye, let him live freely, and who wants to look after his property, let him look after and live freely" (Dyaryusz, 1858: 43). So the Cossack leaders saw the future of Ukraine as part of the Polish-Lithuanian Commonwealth in democratic forms of government.

It is likely that the moods in the Cossack environment influenced on the formulation of "The Ordinatsii (Resolution) of Zaporizhzhya Registry Army", which was approved by the general Seim in the spring of 1638 . According to the resolution, the Cossacks were forbidden to live in cities other than the border - Cherkasy, Chigirin and Korsun to prevent any possible opposition against the local government. Obviously, the territorial restriction of habitats became the impulse for the continuation of the Cossack rebellion in the summer of 1638 . Hetman Dmitry Huni's message repeats the thesis of a vision of a unified community of residents of the Dnieper region whose interests should be protected. "Obviously," the document says, "there is no truth or fear of God here, whether let it be with us, to conduct war with the Zaporozhian Army, who dared to sacrifice our lives and surrendered to the will of the highest God for our bloody merits and for that innocently shed our blood, and indeed the innocent and poor people were given the peace that the voice and the innocent blood spilled cry out for vengeance to God and excite us to that" (Reunion, 1954, 1: 237).

More successfully, the idea of Cossack autonomy under the flag of Orthodoxy was realized with the start of the Liberation War. During the negotiations of the rebellion leaders with the embassy of the Crown Hetman Mykola Potocki in Zaporozhian Sich in March 1648 requirements were formulated, the main one was concerned with the withdrawal of the kwartz (hired) army from the "Dnieper and Ukraine" and abolished here the "management of the Polish-Lithuanian Commonwealth". That is, it was about the separation of the Cossack region into the autonomous formation of the Polish-Lithuanian Commonwealth. The victory of the Ukrainian army under Zhovti Vody and Korsun fortified its position. In universals of Bohdan Khmelnitsky which were distributed among population response, there was an intent to liquidate the current authorities, and to indroduce its own which is led by hetman. The absence of complete sources is not allowed to find out the status of new formation in the Dnieper, obviously, there is region with broad autonomous rights. Anyway the realization of the plan should lead to the satisfaction of Cossack needs and strenthening of the royal power as a guarantee of restraint of magnate and noble outrage. At the same time, Vladyslav IV death significantly influenced plans of B. Khmelnitsky. Having lost the protector in a person of the King, the Cossacks paid attention on the
Orthodox Moscow Tsar Alexei Mikhailovich as a potential candidate for the throne of the Polish-Lithuanian Commonwealth. Thanks to his support, it was planned to equate the Cossack status with the nobility and to create wide autonomy in "Ukraine". The candidacy of the Transylvanian prince seemed also promising in the Cossacks view. Unjustified expectations forced B. Khmelnitsky to support Jan Kazimir's candidacy for the monarchic throne. According to some researchers, this led to a military campaign on Western lands, during which the hetman articulated more moderate proposals, in particular to increase the number of the registry army, protection of the Orthodox Church and subordination of the Zaporozhian Army exclusively to the King.

A powerful factor for the hetman's realization of the purpose of the struggle was his meeting with Jerusalem Patriarch Paisii in late 1648. In European political life, the consecration of a ruler of the state by a hierarch was one of the most important elements in recognizing his divine rights. According to legends, a similar rite was held over B. Khmelnitsky. Thereby his power was recognized as "Prince of Rus" all over the territory which was controlled by the Cossacks (Plokhii, 2005: 293). Cossack ambassador to Moscow Siluyan Muzhilovsky at the beginning of 1649 emphasized the fact that freed territory from the Poles "became permanently their Cossack land, not Polish and not Lithuanian" and they live "freely" in those places (Kryp Svidkevich, 1990: 226).

Royal commissioners also noted the radial change in Hetman's behavior and self-esteem during negotiations in Pereyaslav in February 1649. In the same place, B. Khmelnitsky announced the intention to merge all Rusian / Ukrainian lands in ethnic boundaries by pointing to the Western border "along Lviv, Holm and Halych" (Reunion, 1954, 2: 118). In fact, for the first time the hetman officially declared his intention to create independant Ukrainian state.

\section{Conclusions}

The main principles of self-government as an important factor of autonomy were formulated by the leaders of Zaporozhian Sich. This led to the appearance of various political projects, in which the leading role was assigned to the Zaporozian Army. Cossack's struggle for rights and privileges coincided with the escalation of the denominational situation in Ukraine. The union of the Cossack leaders with the Orthodox hierarchs in the first half of the XVII c. promoted awareness of the positions of both parties in conditions of Polish expansion. During the Cossack rebellions, among the slogans of their leaders, an important place belonged to the protection of Orthodoxy. Social ideals and political values cherished by Cossacks became the catalyst for state formation in Ukraine which manifested itself in the idea of Cossack autonomy within the PolishLithuanian Commonwealth.

\section{REFERENCES}

Akty, otnosyashchiesya $k$ istorii Yuzhnoy $i$ Zapadnoy Rossii (1865). T. 2. Sankt-Petersburg. (in Russian).

Arkhiv Yugo-Zapadnoy Rossii (1863). Ch. 3. T. 1. Kiev. (in Russian). Boretsky, I. (1988). Protestatsiya. Pamyatky bratskykh shkil na Ukrayini. Kinets XVI - pochatok XVII st. Kyiv: Naukova dumka, 313-327. (in Ukrainian).

Vikul, P. (1894). Kievskiy mitropolit lov Boretskiy (1620-1631 gg.). Podolskie eparkhialnye vedomosti. № 27. 513-522. (in Russian).

Vossoedinenie Ukrainy s Rossiey. Dokumenty i materialy: $v 3 t$. (1954). Moscow: Iz-vo AN SSSR. T. 1. T. 2. (in Russian).

Holobutsky, V. O. (1994). Zaporozke kozatstvo. Kyiv: Vyshcha shkola. (in Ukrainian). 
Hrushevsky, M. (1995). Istoriya Ukrayiny-Rusy. Kyiv: Naukova dumka. T. 7. T. 8. (in Ukrainian).

Zherela do istoriyi Ukrayiny-Rusy (1908). Lviv, T. 8. (in Ukrainian).

Zhukovich, P. (1906). Seymovaya borba pravoslavnogo zapadnorusskogo dvoryanstva s tserkovnoy uniy. Sankt-Petersburg, 1906. V. 3. (in Russian)

Krypyakevych, I. P. (1990). Bohdan Khmelnytsky. Lviv: Svit. (in Ukrainian).

Nalyvaiko, D. (1992). Kozatska khrystyyanska respublika. Kyiv: Dnipro. (in Ukrainian).

Plokhii, S. (2005). Nalyvaikova vira: kozatstvo ta relihiya $v$ ranniomoderniy Ukrayini. Kyiv: Krytyka. (in Ukrainian).

Sas, P. M. (1992). Proekt Zadniprovskoyi kozatskoyi derzhavy Yosypa Vereshchynskoho: polityko-pravovyy aspekt. Ukrayinska kozatska derzhava: vytoky ta shlyakhy istorychnoho rozvytku. Cherkasy, 59-61. (in Ukrainian).

Selyanskyy rukh na Ukrayini 1569-1647 rr. Zbirnyk dokumentiv i materialiv (1993). Kyiv: Naukova dumka. (in Ukrainian).

Shcherbak, V. O. (2006). Ukrayinske kozatstvo: formuvannya sotsialnoho stanu. Druha polovyna XV - seredyna XVII st. Kyiv: Vyd. dim "KM Academia". (in Ukrainian).

Dyaryusz transakcyi wojennej między wojskiem koronnem i zaporoskiem... przez ojca Szymona Okolskiego (1858). Kraków. (in Poland).

Kronika Polska Marcina Bielskiego (1856). Sanok. T. 3. (in Poland). Listy Stanisł awa Żoł kiewskiego 1584-1620 (1886). Kraków. (in Poland).

Pisma Stanisł awa Żoł kiewskiego (1861). Lwów. (in Poland).

Wereszczyński, J. (1911). Droga pewna. Sbornik statey i materialov po istorii Yugo-Zapadnoy Rossii. K. V. 1, 12-15. (in Poland).

\section{LIST OF REFERENCE LINKS}

Акты, относящиеся к истории Южной и Западной России. Санкт-Петербург, 1865. Т. 2. 287 с.

Архив Юго-Западной России. К., 1863. Ч. 3. Т. 1. 433 с.

Борецький І. Протестація. Пам'ятки братських шкіл на Україні. Кінець XVI - початок XVII cm. К.: Наукова думка, 1988. C. $313-327$.
Викул П. Киевский митрополит Иов Борецкий (1620-1631 гг.). Подольськие епархиальные ведомости. № 27. 1894. C. 513-522.

Воссоединение Украины с Россией. Документы и материалы: в 3 т. Москва: Из-во АН СССР, 1954. Т. 1. (16201648 гг.). 587 с.; Т. 2. (1648-1651 гг.). 585 с.

Голобуцький В. О. Запорозьке козацтво. К.: Вища школа, 1994. 537 c.

Грушевський М. Історія України-Руси. К.: Наукова думка, 1995. T. 7.624 c.; T. $8.385+288$ c.

Жерела до історії України-Руси. Львів, 1908. Т. 8. 407 с.

Жукович П. Сеймовая борьба православного западнорусского дворянства с церковной уний. Санкт-Петербург, 1906. Вып. 3. 203 с.

Крип'якевич І. П. Богдан Хмельницький. Львів: Світ, 1990. $406 \mathrm{c}$.

Наливайко Д. Козацька християнська республіка. К.: Дніпро, 1992. 495 c.

Плохій С. Наливайкова віра: козацтво та релігія в ранньомодерній Україні. К.: Критика, 2005. 494 с.

Сас П. М. Проект Задніпровської козацької держави Йосипа Верещинського: політико-правовий аспект. Українська козацька держава: витоки та шляхи історичного розвитку. Черкаси, 1992. С. 59-61.

Селянський рух на Україні 1569-1647 рр. Збірник документів і матеріалів. К.: Наукова думка, 1993. 534 с.

Щербак В. О. Українське козацтво: формування соціального стану. Друга половина XV - середина XVII ст. К.: Вид. дім "KM Academia", 2006. 297 c.

Dyaryusz transakcyi wojennej między wojskiem koronnem i zaporoskiem... przez ojca Szymona Okolskiego. Kraków, 1858. $200 \mathrm{~s}$.

Kronika Polska Marcina Bielskiego. Sanok, 1856. T. 3. 1223 s.

Listy Stanisława Żołkiewskiego 1584-1620. Kraków, 1886. $152 \mathrm{~s}$.

Pisma Stanisława Żołkiewskiego. Lwów, 1861. $628 \mathrm{~s}$.

Wereszczyński J. Droga pewna. Сборник статей и материалов по истории Юго-Западной России. К., 1911. Вып. 1. C. 12-15.

Віталій Щербак,

Київський університет імені Бориса Грінченка (м. Київ, Україна)

e-mail: shcherbak.vitalii@gmail.com, ORCID 0000-0001-8025-5684

\section{ПРАВОСЛАВ'Я ЯК ПРАПОР БОРОТЬБИ ЗА КОЗАЦЬКУ АВТОНОМІЮ В СКЛАДІ РЕЧІ ПОСПОЛИТОЇ}

Актуальність статті обумовлена потребою розкриття генези державотворчих процесів в Україні як частини європейського соціокультурного простору Нового часу. Мета студії полягає у з'ясуванні основних засад і шляхів формування ідеї козацької автономії в Речі Посполитій наприкінці XVI - першій половині XVII ст. Методологія заснована на застосуванні загальнонаукових (аналіз, синтез, ретроспекція) та специфічно історичних (проблемно-хронологічних, історико-порівняльних та критично-аналітичних) методів наукового дослідження. Аргументовано висвітлено ґенезу самоврядування запорозької спільноти та поширення їі принципів на територію Подніпров'я. Увага акцентується на ролі православ'я в цьому процесі через спілку очільників Війська Запорозького та українських духовних ієрархів. Автор доводить, що засади самоврядності як важливого чинника автономії були сформульовані на Запорозькій Січі. Це зумовило появу різних політичних проектів, в яких провідна роль відводилася Війську Запорозькому. Союз козацької верхівки 3 православними ієрархами сприяв усвідомленню позицій обох сторін в умовах польської експансії. Повною мірою він проявився під час козацьких повстань в Україні 20-30-х років XVII ст., що зумовило формування ідеї козацької автономії в межах Речі Посполитої. Результати дослідження сприятимуть вивченню еволюції державної ідеї в ранньомодерній Україні.

Ключові слова: українське козацтво; козацька автономія; православ'я; Військо Запорозьке; духовні ієрархи.

(C) Vitalii Shcherbak

Надійшла до редакції: 24.09.2019

Прийнята до друку: 11.10.2019 